University for Business and Technology in Kosovo

UBT Knowledge Center

Oct 27th, 10:45 AM - 12:15 PM

\title{
Energy Efficiency for a farm company in the Po Valley: NZEFC - Nearly Zero Energy Farm Company
}

Kliton Bylykbashi

Sapienza University of Rome, kliton.bylykbashi@uniroma1.it

Follow this and additional works at: https://knowledgecenter.ubt-uni.net/conference

Part of the Engineering Commons

\section{Recommended Citation}

Bylykbashi, Kliton, "Energy Efficiency for a farm company in the Po Valley: NZEFC - Nearly Zero Energy Farm Company" (2018). UBT International Conference. 148.

https://knowledgecenter.ubt-uni.net/conference/2018/all-events/148

This Event is brought to you for free and open access by the Publication and Journals at UBT Knowledge Center. It has been accepted for inclusion in UBT International Conference by an authorized administrator of UBT Knowledge Center. For more information, please contact knowledge.center@ubt-uni.net. 


\title{
Energy Efficiency for a farm company: NZEFC - Nearly Zero Energy Farm Company. Case of Study
}

\author{
Kliton Bylykbashi \\ Giuseppe Bonifazi ${ }^{2,1}$, Riccardo Gasbarrone ${ }^{2,2}$, Silvia Serranti ${ }^{2,3}$ \\ University Education for Business and Technology - UBT \\ "Lagja Kalabria" p.n. 10000 Prishtine \\ \{kliton.bylykbashi@ubt-uni.net\}
}

${ }^{2}$ Department of Chemical Engineering, Materials \& Environment.

Sapienza University of Rome, Via Eudossiana 18, 00184, Rome, Italy

Research Center for Biophotonics, Sapienza University of Rome.

Corso della Repubblica 79, 04100, Latina, Italy.

\{giuseppe.bonifazi, riccardo.gasbarrone, silvia.serranti\}

duniroma1.it

\begin{abstract}
In this report, the energy consumption of 25 agricultural companies, which produce milk for the Soresina consortium, was evaluated.The purpose was to determine a Standard Energy Diagnosis Procedure (SEDP), for the agricultural sector. In the case of study below, the farm company has decided to adhere to a process of technological renewal, able to reduce to zero, the energy consumption, related to electricity and agricultural naphtha. Three are the intervention that the company has decided to adopt: Integration the photovoltaic system with a Storage System (battery); castrating a new biogas plant, with $75 \mathrm{~kW}$ electrical power; replacing the unifeed wagon with a robot: Trioliet

Triomatic T15, coupled with the kitchen Triomatic T30.
\end{abstract}

Keywords: Energy Efficiency, Standard Energy Diagnosis Procedure, Zero Energy Consumption, Renewable Energy.

\section{Introduction}

The European Union (EU) is facing a serious challenge to reduce dependence on oil and energy imports, to limit climate change and overcome the economic crisis. The Energy Efficiency is a valuable tool for dealing with these hostilities.

The States of the EU met and set up action plans to reduce energy consumption thanks to some directives (including the Directive 27/2012). Only some companies and buildings are obliged to carry out an energy diagnosis or energy audit. - big business enterprises;

- energy-consuming companies;

management system (eg: EMAS, ISO 50001, EN ISO 14001) and have the first tow characteristic.

Food, in Europe, represents the most important sector of the manufacturing industry with a presence of small and medium-sized enterprises, of over $90 \%$ distributed mainly in the South of Europe.

Only $1 \%$ of companies in the sector, can be classified as "big business". The agriculturalfood system produces less than 5 billion tons a year of food products, of which about 2.4 billion tons of fruit and vegetables.

\section{Corporate data}




\subsection{Company Descriptio}

The company "SOLDI IGINO AND FRANCESCO S.S. SOCIETA 'AGRICOLA "is located in Pieve d'Olmi, in: Via Marconi, 5 - 26040 - municipality of Cremona. The company produces pasteurized bovine milk, for the "Latteria Soresina SPA", and all the supply of agricultural products for the feeding of the bovine units, comes from the processing of 300 ha of agricultural land available to the company. In the energy assessment, the consumption of agricultural naphtha was also included in the machines, which work fields with different processes according to seasonality. The farm of Igino and Francesco Soldi, from Pieve d'Olmi, Cremona, is made up of 2 stables: one has been renovated in 2014 for which it has fixed and grated bedding; the second has a fixed litter with external concrete enclosures. There are 250 beds for the dairy cattle units. Five mechanical guides, useful for cleaning, cross the stalls. Milking, the main activity of the building, takes place twice a day for about $3-4$ hours; the milk produced is stored in a cold store and then sent to Soresina, and this process is not managed by the farm company, but by the outsourcing firms. The processing of the fields has seasonality, and the products are all stored in silos or trenches to feed the bovine units.

\subsection{Pv Plants}

In the building, there is a PV plant of $69.23 \mathrm{kWp}$ installed in December 2012 by Germal Ltd.

The photovoltaic system consists of $n^{\circ} 2$ photovoltaic generators composed of $n^{\circ} 322$ photovoltaic modules and of $\mathrm{n}^{\circ} 5$ inverters with architectural classification on building.

The total nominal power is $69.23 \mathrm{kWp}$ for a production of $71.900 \mathrm{kWh}$ per year (which are not verified, data of the manufacturer), distributed over an area of $483 \mathrm{~m}^{2}$.

\section{Energy Diagnosis}

3.1 Results of the energy diagnosis

Based on the template provided by Decree Law 102 of 2014, energy consumption has been subdivided according to the process, auxiliary and general services.

Table 1. Consumption of main activities/process (data: 1 year: 2014 -2015)

\# Electricity Consumption kW kWh TEP 1 Milking machine 7.5 13,100 2.5 1 Milking pump 1.5876 0.2 Consumption fossil fuel

1 Taren 185 hp 136 66,654 8.0 1 Case MXU 135 hp 99.3 48,640 5.8 1 Manitu 75 hp 55.1 27,022 3.2 1 New Hollan 100 hp 73.5 18,787 2.3 1 Fiat 90 - 130 hp 80.9 20,665 2.51 Agrifus 60 hp 44.1 10,809 1.32 Ferguson $60 \mathrm{hp} \mathrm{88.2} \mathrm{21,618} \mathrm{2.6} 1$ Unifeed Carro Semovente 117.6 90,176 10,8 TOT 318,387 39.1

Table 2. Consumption of auxiliaries service (data: 1 year: 2014 - 2015)

\# Electricity Consumption kW kWh TEP 1 Milk storage fridge 5 21,900 4.15 Mechanical guides for cleaning the stables $2012,5472.318$ Fans $3642,1207.8$ TOT 76,567 14.3

Table 3. Consumption of general service (data: 1 year: 2014 - 2015)

\# Electricity Consumption kW kWh TEP 2 Electric heater 1.5 - 2.2 12,864 2.3 1 Small refrigerator 0.49200 .21 Freezer 0.37880 .1 1 Boiler $1412,2642.342$ Light $0.1-0.71,2810.2$ TOT 28,067 5.1

The total results in tons of oil equivalent (TOE) are:

- Electrical requirements: $22.8 \mathrm{TOE}$

- Agricultural naphtha requirements: $36,5 \mathrm{TOE}$

Analyzing the electricity and fuel consumption of the year (from December 2014 to December 2015), the data were deviating from the engineering analysis by a value of less 
than $5 \%$. This has reported, to validate the diagnostic procedure, as correct.

The evaluations of the energy bills of the last year considered, propose the following unit costs:

- $€$ 0.65/1 of agricultural naphtha;

$\bullet € 0.21 / \mathrm{kWh}$.

\title{
4. Towards the solution of: Nearly Zero Energy Farm Company
}

Once armed with the results of the energetic diagnosis, it was decided to proceed with interventions, than have to reduce the energy consumed (stable - offices) of the company, closer to zero. The tractors that work the fields have not been taken into consideration, but only, those used in the stable.

There were three recommended intervals, summarized in the following table:

Table 4. Evaluation of energy efficiency

$\begin{array}{lll} & \text { INTERVENTION } & \text { DESCRIPTION } \\ \text { TYPE OF } & \text { AREA OF } & \text { ENERGY SAVING } \\ & \text { INTERVENTION } & \text { PAYBACK TIME }\end{array}$

(Years)

Plant All Integration of the $<17,7 \% 1.9$

photovoltaic

system with a

Storage System

(battery)

Plant Process/main

activities

Replacing the unifeed

$\begin{array}{lll} & \begin{array}{l}\text { Plant All Integration of a biogas plant } \\ >100 \% 5.7\end{array} \\ & & \text { energy } \\ \begin{array}{l}\text { wagon with a robot / } \\ \text { modifications of the }\end{array} & \begin{array}{l}30 \% \\ \text { stable and food } \\ \text { distribution for the }\end{array} & 6 \\ \text { animals } & 100 \% \text { of stable } & \end{array}$

Plant All Integration of a biogas plant

$30 \%$

$100 \%$ of stable

4.1 Intervention of energetic efficiency n.1. Connection package batteries

The first proposed intervention is the integration of a package batteries Rolls Serie 5000 Bench Batteries 48 Volts $119.52 \mathrm{kWh} \mathrm{C100.} \mathrm{The} \mathrm{cost} \mathrm{of} \mathrm{the} \mathrm{element} \mathrm{is} \mathrm{of} \mathrm{around} 12.000 €$ + IVA.

The battery will be dimensioned to work to $60 \%$ some his/her own abilities, for which it will have an useful life of around 2.800 cycles for 10 years. This intervention ago him that the absorbed energy to the net a year is smaller then $20.000 \mathrm{kWh}$, reducing so the tied up costs to the energy bought by the society. The principal data of the intervention of energy efficiency, are explain in the table below.

Table 5. Results of the intervention

\author{
Energetic saving for one year $20,995 \mathrm{kWh}$ \\ Monetary saving for one year $4,199 €$ \\ TOE saving for one year 4 \\ $\mathrm{CO}_{2}$ saving for one year $11,148 \mathrm{~kg}$ \\ CAPEX $12,300 €$ \\ OPEX $0 €$ \\ Pay Back Time $\mathrm{PBT}_{\text {simple }} 3$ years
}




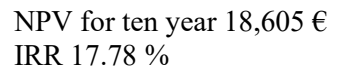

\subsection{Intervention of energetic efficiency n.2. Plant Biogas}

The agricultural firm counts a breeding of 435 bovine heads, and around 300 hectares of cultivable fields of ownership plus 100 ha of the cooperative with which it collaborates.

It is decided to cover the electric requirement of the society, with the plant biogas. The electric energy produced in excess by the plant, will sell to the electric net, according to a stimulating rate of $0,23 € / \mathrm{kWh}$ as established by the MD (Ministerial Degree) of 6 July 2012.

Insofar the choice reverts, on an unity Heat Power Combined from $75 \mathrm{~kW}$ of electric power. In the specific one, the motor "Filius R06" produced by the German firm 2G Energietechniks; the plant has the followings characteristic:

Table 6. Characteristics of the plant

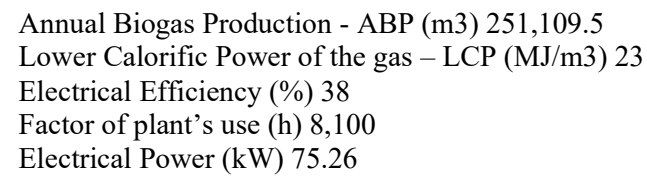

In the chart number 7 are brought the characteristics technical economic of the intervention.

Table 7. Results of the intervention

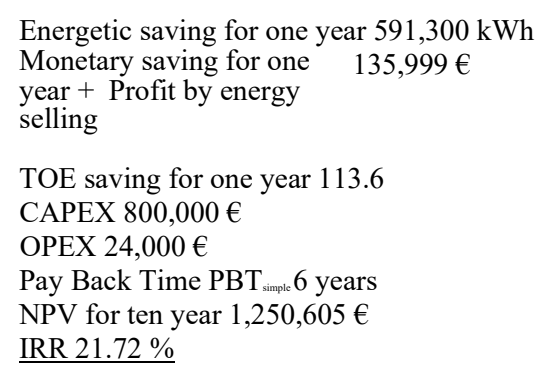

4.3 Intervention of energetic efficiency n.3. Substitution of the self moving wagon UNIFEED with the robot Trioliet Triomatic T15

From the budget of the costs of the energy employed in the firm, which is composed of electric energy and agricultural naphtha, it is deduced that the tallest percentage of the costs $(60 \%)$ is tied up to the use of the agricultural cars.

The machinery that has the greatest consumption of agricultural naphtha, around $30 \%$, it is the self moving wagon that mixes and it grinds the food necessary Unifeed to the bovine unities and it distributes it along the passage of feeding inside the stall. The self-moving wagon is equipped by a motor diesel John Deere with power of $160{ }^{\mathrm{hp}}$. It is held opportune to replace the wagon Unifeed with a robot that stirs on the platforms that circumscribe the stall.

The robot of feeding chosen is the TRIOLIET Triomatic T15, coupled with the kitchen Triomatic T30.

The robot has 4 wheels 2 of which engines, that allow the traction withdrawing electric energy from the line with creeping contacts. This type of feeding is advantageous because, 
it doesn't need the installation of suspended rails but only of the aerial line crossed from current.

The absorbed average power during the operation is of $4 \mathrm{~kW}$. The daily operation is esteemed in 6 hours, had been dividing in 2 turns for 3 hours every, accordingly the middle energy daily consumed is $24 \mathrm{kWh}$, and in one year $8.760 \mathrm{kWh}$. The robot needs a feeding in alternating current trifase to $400 \mathrm{~V}$.

In the chart number 8 are brought the technical economic characteristics of the intervention.

Table 8. Results of the intervention

\author{
Energetic saving for one year 12,9171 \\ Monetary saving for one year $8,396 €$ \\ TOE saving for one year 10.9 \\ $\mathrm{CO}_{2}$ saving for one year $34,230 \mathrm{~kg}$ \\ CAPEX 220,000€
}

\title{
OPEX 7,000€
}

Pay Back Time $\mathrm{PBT}_{\text {simpk }} 26$ years

NPV for ten year N.C.

IRR N.C.

The cost of the investment is not economic for the company, but the actual Unifeed Machines, result old and obsolete. The new one cost more then 120,000 $€$ and need the present of a specialized worker, who has a annual salary about $35-45,000$ of euro. Thanks the incentive and the reductive cost of the specialist, result better the investment of TRIOLIET Triomatic T15, then the new one Unifeed.

\section{Result}

The three suggested interventions have considerably reduced the energy consumption of the agricultural company, conferring a high technological value. The 128.5 TOEs saved each year by these interventions, are the consequence of a high environmental and economic benefit. After this energy requalification intervention, this project was a pilot for the achievement of energy audits in the agri-food sector.

\section{References}

[1] Vincenti, "Photovoltaic systems for self-consumption", IESL, 2017.

[2] A. Calabria, D. Di Palma, M. Di Veroli, M. Lucentini, "the Expert in Energy Management", EPC Editore, 2016.

[3] Agency for Energy and Sustainable Development of Modena: Energy Diagnosis, the international regulatory framework and the UNI TIR Standard 11 428, 2016. [4] C. Benedetti, "Thermal Bridges", Master House Climate, 2016.

[5] G. Roberto, "Energy diagnosis in municipal buildings" ASSOEGE, 2015. [6] All Normen and GSE, "The Blue Guides" 15 Photovoltaic, Publisher TNE, 2015. [7] E. Bocci, A. Caffarelli, A.

D'Amato, A. Di Carlo, M. Villarini, "Biomass systems: Heat, electricity and biomethane generation plants", 2nd edition, 2015.

[8] Nie, H., Jacobi, H. F., Strach, K., Xu, C., Zhou, H., Liebetrau, J., "Mono-fermentation of chicken manure: Ammonia inhibition and recirculation of the digestate". Journal of Bioresource Technology, Volume 178, February 2015

[9] C. Mariani, S. Alessandro, "The control of cash flow. How to forecast and manage the Cash Flow for financial soundness ", 2014.

[10] S. L. Dixon, C. A. Hall, "Fluid Mechanics and Thermodynamics of Turbomachinery", Oxford, Butterworth-Heinemann, 2014.

[11] Jiang, A., Zhang, T., Zhao, Q., Li, X., Chen, S., Frear, CS. "Evaluation of an integrated ammonia stripping, recovery, and biogas scrubbing system for use with anaerobically digested dairy manure ", 2014 
[12] By Franco N., "Energy management. Fundamentals for the assessment, planning and control of energy efficiency ", Franco Angeli 2014.

[13] Liu, L, Pang, C., Wu, S, Dong, R, "Optimization and evaluation of an air-recirculated stripping for ammonia removal from the anaerobic digestate of pig", 2014. [14] C. Ledda, A. Schievano, S. Salati, F. Adani, "Nitrogen and water recovery from animal slurries by a new integrated ultrafiltration, reverse osmosis and cold stripping process: A case study". Water Res. 47, 6157-6166, 2013.

[15] F. Arecco, "Energy from biogas: manual for planning authorization and management of plants", 2013.

[16] Lanzoni D., "Diagnosis and energy certification: instrumental tests on buildings", Mggioli Editore, 2012

[17] A. Calabria, R. Capata, "A 20 MW case study. Technical feasibility analysis and economical aspects ". Journal of Engineering (ENG) (volume 4 No. 9), June 2012. [18] Luca Rubini, Silvia Sangiorgio, "Renewable Energy", Rome, Hoepli, 2012. [19] Introna V., Berretta F., Saccardi D., De Carlo F., "Designing and managing energy efficiency", Mc Graw - Hill, 2012 